\title{
Labour Universities: Physical Education and the indoctrination of the working class.
}

Patricia Delgado-Granados

Gonzalo Ramírez-Macías

This paper explores the role of Physical Education in Labour Universities (1955-1978) during Franco's regime as an instrument of indoctrination and declassing of the working class. The conclusions obtained after the study and the analysis of various primary sources indicate that, initially, Physical Education was used as an instrument of indoctrination for the purposes of achieving the social and ideological model of Franco's regime after the Fascist uprising (1936-1939). However, this initial orientation became less relevant in the Sixties, in favour of the inherent aspects of sport, which contributed to the declassing of the young workers. In fact, Labour Universities became national benchmarks in the area of sports within the education system. Physical Education lost its indoctrinating and declassing roles after the General Law of Education was passed in 1970, and the focus shifted instead to its role as an activity for participation, education, and comprehensive training. 


\section{Introduction.}

Labour Universities represented a typical institutional model of Franco's Regime for the working class, which included not only the workers but also their children. Since their establishment in 1955 until their decline in 1978, twenty-one Labour Universities were established in Spain, and more than half a million students were educated within them.

Labour Universities were considered the universities of the poor, and they represented the main tool for social promotion and indoctrination of the working class.

One of the main goals of the Labour Universities was the regulated and non-regulated training of the working class, as an effective mechanism to eliminate the republican inheritance, which was based on the militancy and the growth of the unions. The dictatorship put an end to this plurality, while at the same time it introduced a vertical union structure in order to control the workers, and a complex education system to qualify the working class, based on the Falangist and nationalCatholicism ideologies. The task was to forge the new man in all of his dimensions, which required a double training action: professional and human, basing the human aspect on the political and physical education as elements of submission and control of the working class. Franco's will was focused on shaping ideological parameters which would erase the identity signs of the working class and the class struggle, aligning them and unifying them within the idea of the social, political and ideological unity of Facism.

This paper analyses the mechanisms for indoctrination promoted through Physical Education in Labour Universities. The material used for the analysis consists of documents which were produced and published between 1955 and 1978 by the Regime itself and by official institutions linked to the Regime (e.g. legislation, fundamental political texts, ideology of the government hierarchs, legal system, propaganda, etc.), as well as previously published research which has touched on the subject of this paper.

In this sense, the originality of this research lies in that not only the subject of Physical Education in Labour Universities has been seldom studied, but also that these macro institutions were created in the mid-Fifties, at a time when the openly controlling and indoctrinating character of Physical Education was losing relevance in favour of a more subtle way of exercising control and indoctrinating, which was focused on athletic performance ${ }^{1}$. In this regard it is noteworthy that, apart from the research from González $\mathrm{Aja}^{2}$, there is no other reference research on Physical Education within the developmental period (1959-1975). Due to this, it was necessary to increase the research about this historical period, which has played a major role on the current configuration

\footnotetext{
${ }^{1}$ There are many previous researches about Physical Education during Franco's regime, which distinguish between a first period with a clear fascist and indoctrinating character, and a second period in which sport became the leading light (or 'star')of Physical Education. The majority of this research is of a general nature and they focus on the most fascist period of the regime. See for example: Carmen Carbajosa, Las profesoras de Educación Física en España: Historia de su formación (1938-1977) (Oviedo: Universidad de Oviedo, 1999); Alejandro De la Viuda, 'Deporte, censura y represión bajo el franquismo (1939-1961)', in Atletas y ciudadanos. Historia social del deporte en España (1870-2010), ed. Xavier Pujadas (Madrid: Alianza, 2011), 273-322; Teresa González Aja, 'Fascists and Christians! in the Spanish martial tradition of the soldier-monk', The International Journal of the History of Sport 16/4 (1999): 119-144; Juan Carlos Manrique, 'La Educación Física femenina y el ideal de mujer en la etapa franquista', Revista Internacional de Medicina y Ciencias de la Actividad Física y el Deporte 3/10 (2003): 83-100; Carles Santacana, 'Espejo de un régimen. Transformación de las estructuras deportivas y su uso político y propagandístico (1939-1961)', in Atletas y ciudadanos. Historia social del deporte en España (1870-2010), ed. Xavier Pujadas (Madrid: Alianza, 2011), 205-232. It is, however, important to stress that there is no previous research in regards to Physical Education and sport in Labour Universities.

${ }^{2}$ Teresa González Aja, 'Contamos contigo. Sociedad, vida cotidiana y deporte en los años del desarrollismo (1961 1975)', in Atletas y ciudadanos. Historia social del deporte en España (1870-2010), ed. Xavier Pujadas (Madrid: Alianza, 2011), 323-356.
} 
of Physical Education in Spain.

This research focuses specifically on a type of institution in which Physical Education played an important role in the creation of the new 'worker', as reflected by the interest in sporting competitions and by the fact that Physical Education was taught daily. Similarly, Labour Universities stood out due to the high quality of their sport and teaching facilities, which surpassed to the existing school buildings. Some of the legacies of Labour Universities include Olympic swimming pools, track and field spaces, sports fields, fronton courts, velodromes, or bowling centres.

The first part of this paper offers a general context to this research (Franco's dictatorship) followed by a specific context (Labour Universities and Physical Education during Franco's regime). Next, it is shown how Physical Education took place in Labour Universities, looking at this subject from the different aspects that defined it: theoretical conceptualisation, teaching staff, content, competitions and, in particular, the ideological training which was present across all the aforementioned aspects. Finally, conclusions are drawn - the most relevant of them being the fact that Physical Education in Labour Universities had a primarily indoctrinating character at the beginning but, following the political changes it quickly evolved towards the search for athletic excellence. The indoctrinating aspect took on a more subtle character on this second period, and it contributed especially to the declassing $^{3}$ of the young workers.

\section{Franco's dictatorship. Special reference to the development period.}

The victory of the Fascist uprising (1936-1939) also meant the victory of the Church and the rightwing groups which had fought so hard against the Second Republic. Franco's new dictatorial political system (1939-1975) was ideologically based on the Movimiento Nacional, which was a totalitarian structure of fascist influence that intended to be the sole mechanism for participation in the public aspect ${ }^{4}$. The most important branch of the Movimiento Nacional was represented by a single political party, called Falange Española Tradicionalista y de las Juntas de Ofensiva Nacional Sindicalista (F.E.T y de las JONS) ${ }^{5}$. Other important institutions which were part of the Movimiento and which had an impact on the Spanish social life were the Vertical Syndicate; the Youth, Education and Rest Front; and the Feminine Section ${ }^{6}$.

Using this system of organisations as a base and through an authoritarian government, Franco advocated a nationalistic policy in which traditional and Catholic values were present. Franco sought to maintain this policy throughout the dictatorship, but the financial limitations in Spain were too evident at the beginning of the 1950s. Franco first opted for isolation, just like the Communist dictatorships had done previously but following the failure of this approach, he then opted for the only actual solution: to open the financial arena to liberal capitalism. The most prominent action taken in this regard was the Stabilization Plan of 1959, which created an important weathering on the ideology of the Regime ${ }^{7}$.

This weathering, the political necessity of the dictatorship allying with the winning nations of World War II and the financial need to step out of the underdeveloped state which Spain had become after the Civil War and the autarkic policies of the Regime, forced an incorporation of democratic-occidentalist measures. In this context, Franco fell into remarkable contradictions,

\footnotetext{
${ }^{3}$ The term 'declassing' will be used throughout our paper to refer to the phenomenon by which the working class lost the awareness of belonging to their own social class.

${ }^{4}$ Stanley G. Payne. El primer franquismo, 1939-1959 (Madrid: Temas de Hoy, 1997).

${ }^{5}$ Paul Preston. El gran manipulador. La mentira cotidiana de Franco (Barcelona: Ediciones B, 2008).

${ }^{6}$ Stanley G. Payne. El franquismo. Primera parte (Madrid: Arlanza, 2005a).

${ }^{7}$ Stanley G. Payne. El franquismo. Segunda parte (Madrid: Arlanza, 2005b).
} 
which were a result of the incompatibilities between the unavoidable financial modernisation required and the social, cultural and religious model for which he had rooted from the very beginning of the dictatorship.

However, before this necessary change of direction, Franco always tried to keep the domestic political climate as unaffected as possible - in fact, he only made mild changes of an opening character which were essential to maintain good relationships with the European and US democracies. The definite change only happened following the death of Franco in 1975, when the Democratic Transition started.

Despite this, from 1959 until Franco's death, there were many rapid changes in Spanish society. As González $\mathrm{Aja}^{8}$ states, Spain was changing; however, the main player of the change was not the political class but the civil society, who broke away from the anachronistic policy of the Regime and changed the day-to-day life of the Spanish people in regards to education, civil rights, culture, etc. The social aspect of Spanish society evolved, whether the Regime liked it or not. The financial changes transformed Spain into an industrial and urban country; as the rural environment was abandoned for life in the big cities; the social classes evolved - the working class in particular became aware of its own idiosyncrasy; the clandestine syndicates fought for the rights of the workers; there were new problems associated with big cities, such as delinquency and drugs; tourism brought new customs of European imprint - especially sexual liberation ${ }^{9}$. In short, Spanish society tried non-stop to catch up with Western society during the second half of the twentieth century, which would create, in the long run, a society and a culture that was completely different from that envisioned by the Regime ${ }^{10}$.

\section{Labour Universities: Universities of the poor.}

The ideology that justified the creation of Labour Universities in the mid-Fifties had, as a base, an immediate goal: to train the working class (both the workers and their children) in the industrial and agricultural areas ${ }^{11}$. The then Minister of Labour, Girón de Velasco, defined this new Falangist project as an essential element to forge 'men apt for social and political coexistence in the models of the New Horizon of Spanish life ${ }^{12}$, and proclaimed that Labour Universities were:

'(...) castles for the new reconquest, where you, and especially your children, will be trained not only to be good workers, which is little, and it's all that your enemies would want. We are going to create huge centers, where we can train not only technically better workers, but also fully formed men, able to deal with the battles of intelligence, trained to deal with the battles of the spirit, politics, and power. We are going to create different men $(. . .)^{13}$.

\footnotetext{
${ }^{8}$ González Aja, 'Contamos contigo', 330.

${ }^{9}$ Ibíd., 331-332.

${ }^{10}$ Payne, franquismo. Primera parte, 22.

${ }^{11}$ The project of phalangist Labour Universities (1955-1978) was inspired by the Université du Travail of Charleroi (Belgium), which was founded in 1903 by Paul Pastur - a lawyer and Law teacher at the University of Liège - with the help of the Ministry of Industry and Labour. Just like in the Belgian model, Labour Universities stood out because of their impressive buildings and the use of decorative symbols. Despite some parallelisms between both educational projects, Labour Universities were created without the involvement of the workers, who however financed them almost entirely through their payments into the Labour Associations. Besides, the political system in Belgium was a democratic one-socialism-, whilst in Spain after the Civil War a fascist dictatorial regime had been imposed, which lasted throughout the existence of Labour Universities.

Source: 'Comisión Interministerial española, presidida por el Ilmo. Sr. Director General de Previsión, sobre la organización de las enseñanzas técnicas y profesionales de la provincia de Hainavi (Bélgica), Universidad de Trabajo Paul Pastur de Charleroi', Caja 2, Signatura Provisional, Archivo Histórico Provincial de Sevilla.

${ }^{12}$ The Labour High School intended to extend secondary education to the vast middle class, as a response from the State to the industrial development. Professionals and technicians in different areas were trained in the new Labour High Schools.

${ }^{13}$ Sección Educación. Universidades Laborales, 'Informe sobre Universidades Laborales emitido por el Ministerio de
} 
The name of Labour Universities caused some controversy and political confrontation because it was not accepted by all of Franco's sectors because some of them considered that technical training should not have a university classification ${ }^{14}$. It was finally decided that the ostentatious name of Labour Universities would be used to classify the High Schools for Vocational Training, as defined in the vocational training reform of 1955, which in this way could be differentiated from the Labour High Schools and the traditional Schools of Arts and Trades which did not have an educational, cultural and humanist syllabus ${ }^{15}$. However, the very name of Labour University responded more to the grandiloquent language of the political system than to the actual meaning of university ${ }^{16}$. In fact, Labour Universities were never regarded as universities in the strict meaning of the word, because they neither provided teaching of an advanced character nor carried out scientific research. As Girón de Velasco stated:

\begin{abstract}
'The word labour can be understood as a notice for future claims of unfulfilled aspirations. It can also be a cold clarification through which we are told: You will become 'workers' at a 'university', but do not dream about being university students, ${ }^{17}$.
\end{abstract}

Picture 1. Practice as the main training element. Workshop at the Labour University of Seville ${ }^{18}$.

The awareness of the value of work as an essential element for rebuilding the country became an immediate goal in all social aspects. The goal was to insert the sacred dignity of labour into the intellectual teaching which defines the essential values of a population (...) herein lies the mission and the responsibility of a revolution relentlessly imposed over the social horizon of Spain', ${ }^{19}$.

However, the intentions of Franco's regime went beyond just trying to give the proletariat a technical specialisation in a trade or industry; it also tried to indoctrinate the working class through the Falangist doctrine. To this effect, the syllabus was used as an indoctrinating instrument for the ideological principles of Franco's national-syndicalism ${ }^{20}$. It was therefore a matter of ingraining the ideology into the proletariat, and encouraging a strict and repressive conscience which would be geared towards sacrifice and effort for the benefit of the Nation, whilst keeping them in fear of retaliation. The ideological submission was a safeguard for Franco and his Regime. The financial and social circumstances in which Spain was immersed allowed the Ministry of Labour to become the sponsor for social promotion of the working class through Labour Universities, under Franco's ideological system harbored by the victorious party ${ }^{21}$.

\footnotetext{
Educación Nacional', Legajo 19154, Archivo General de la Administración.

${ }^{14}$ During the process of creation and discussion of the Statutes of Labour Universities it was proposed that all those words which contained the root 'university' were eliminated (pre-university teachings, university teachings, postuniversity teachings), the reason being to avoid confusion with the teachings administered by the Ministry of National Education.

Source: Sección Educación .Universidades Laborales, 'Carta de 19 de junio de 1958 del Secretario General de la Junta Central de Formación Profesional Industrial, Consejero Técnico de Universidades Laborales al Sr. Presidente del Consejo Técnico de Universidades Laborales', Legajo 19170, Archivo General de la Administración.

${ }^{15}$ 'Ley de Formación Profesional Industrial de 20 de julio de 1955', Boletín Oficial del Estado, 21 Julio 1955. This law differentiated between the Industrial Pre-learning Schools, Industrial Learning Schools, and Industrial Mastery Schools.

${ }^{16}$ Universidades Laborales, 'Memoria del proyecto de Universidad Laboral de Sevilla: consideraciones sobre los aspectos nacionales, sociales y educativos del problema', Caja 2, Signatura Provisional, Archivo Histórico Provincial de Sevilla.

${ }^{17}$ José Antonio Girón de Velasco, Revista UNI 1 (1968): 9.

${ }^{18}$ Universidades Laborales, 'Diapositiva 376', Archivo General de la Administración.

${ }^{19}$ Sección Educación. Universidades Laborales, 'Informe sobre Universidades Laborales emitido por el Ministerio de Educación Nacional', Legajo 19154, Archivo General de la Administración.

${ }^{20}$ Ricardo Zafrilla y Julia Utiel, Universidades Laborales: Aproximación a su historia económica (Albacete: Popular Libros, 2006).

${ }^{21}$ As opposed to other education institutions controlled by the Ministry of National Education. That is why, since the beginning of the dictatorship, the Falange took over the area of Labour, and Labour Universities were part of their scope.
} 
The determinant factor of Labour Universities, which started from the experience already gained by the Labour High Schools of 1949, was not their function - which was partly shared by Labour High Schools and other vocational training institutions -, but their mission of socio-cultural promotion and indoctrination of the working class. According to the first principle of their Provisional Statutes, Labour Universities symbolized the configuration of a 'cultural higher institution in the area of labour, in the humanist, technical and vocational dimensions, founded and maintained, under the supervision of the State, by the Spanish workers, 22 .

One of the main tools which Labour Universities counted on for their mission of socio-cultural promotion and indoctrination, which differentiated them from other educational institutions, was their educational status (i.e. boarding school, semi-boarding school, or day school) ${ }^{23}$, because $90 \%$ of their students accessed them as boarding schools through a scholarship from the Labour Associations. This meant that these students had free access to lectures, registration, textbooks, materials, meals, accommodation, clothing (for labour, sports, and casual wear), and toiletries. They also had access to other services, such as doctors and pharmacists, certificates, academic degrees, or travel from home to the Labour University (the students were allowed six train trips on second class per annum).

The access to the Labour University as a boarding student, which the scholarship granted, implied a total immersion of the student in the university lifestyle, as he stayed at the Labour University throughout the academic year and shared only the holidays with his family. This lifestyle created a certain break from their previous life, which, in the majority of the cases, translated as a lack of integration with their families and a distancing from the idea of belonging to the working class.

This aspect of Labour Universities was the one which received most criticism. The centres, with their luxury and monumentality, provoked the criticism of an important part of the working class, which saw the institutions as a tool of the State to declass the working class and indoctrinate it with the ideology of the regime. Such great expenses were not justified by the training of technicians who, in any event, did not fit very well into the industrial structures of the country. In addition, it was considered that the organisation, lifestyle and atmosphere of the Labour University did not facilitate the integration of the students in their original backgrounds with an awareness of fidelity and fight for the social promotion of the agricultural and industrial worker; but that instead they resulted in the declassing of those students who came from authentic working environments ${ }^{24}$. In any case, it was a matter of training the young workers to not be interested in politics, and to educate them into an enthusiasm for Franco's regime. The new Falangist project aimed towards forging a new and integral man was covered by national media, as it is shown in the newspaper $\mathrm{ABC}$, where the spirit of the institutions is highlighted: ' $(\ldots)$ the Labour University means the apex of the ambition of Spain in regards to establishing peace and justice, especially in regards to true justice $^{25}$.

Nowadays Labour Universities still exist, but they have been transformed into high school; into different types of education institutions and even into university campus. The remains of Labour Universities are just memories of a socio-educational experiment which produced spectacular results and promoted the education and vocational training of more than half a million youngsters

\footnotetext{
${ }^{22}$ 'Orden de 12 de julio de 1956'.

${ }^{23}$ Day-time students were those who obtained benefits from Acción Formativa or a scholarship to study at Labour Universities in the area where they lived. 'Orden de 16 de agosto de 1958. Artículo 60', Boletín Oficial del Estado, 28 Julio 1958.

${ }^{24}$ Licinio de la Fuente, Universidades Laborales y Promoción Social (Madrid: Servicio de Publicaciones del Ministerio de Trabajo, 1971): 5.

25، Justicia Social', $A B C$, July 17, 1955.
} 
and adults from the working class. After more than fifty years since the creation of the first Labour University in Spain, the quality of their sport, educational and service infrastructures had to be maintained in their transformation, since those resources are seldom available today in almost any education centre nationwide.

\section{Physical Education and sport as an instrument of indoctrination. Especial mention to the development period.}

Several organizations were created at the beginning of Franco's dictatorship: the National Delegation of Sports (D.N.D.) in 1941, the Youth Front (F.J.) in 1940, and the Female Section of the Party (S.F.) in 1945 as an independent branch of the Youth Front. These organisations gave shape to Physical Education and sport during the dictatorship, because they used them as political tools in the service of the social model that they tried to impose, in the same way as the Hitler Youth or the Opera Nazionale Balilla had done ${ }^{26}$.

However, the policy on sports did not remain unchanged throughout Franco's dictatorship. The changes, which happened progressively during the development period, allowed for the addition of some nuances, which even though they did not have an opening character, they were at least specifically related to sports and not only indoctrinating. In this way, the National Delegate for Sports, Elola Olaso (1956-1966), moved from an ideological point of view to a technical one, focusing on the promotion of federated sports, the construction of infrastructures for sports, the education of teachers and trainers, the creation of sport clubs, and the idea of spreading the practice of sports to the entire population ${ }^{27}$.

The largest indicator of this change was the enactment of the Law on Physical Education ${ }^{28}$. This law acknowledged Physical Education as an efficient tool in the education environment and as a measure for preventive health, with which it acquired the category of public necessity. Besides, the National Institute for Physical Education was created, with the aim of educating and improving teachers and sports trainers.

From this point, there were further changes in Physical Education and in the sport practiced by the population. Firstly, the operational unit in the organisation of sports in schools went from a division of the F.J. and the S.F. to being dealt with in the school itself, which gave sports and Physical Education a more educational character.

Secondly, the National School Games, which had been created in 1949, settled within the Spanish society. In fact, schools valued teachers of Physical Education based on the number of participants in the Games and the results obtained - and both aspects became an obsession for the teachers.

Thirdly, and closely related to the previous point, sport becomes the main content of Physical Education, because it was an effective mechanism for the teachers to choose and train their students to participate in the Games - since in many cases the teacher's job or their promotion prospects depended on the results obtained in the Games.

This new outlook on Physical Education and sport contributed to the creation in 1966 of the

\footnotetext{
${ }^{26}$ Several previous researches expose how Physical Education and sport were used by Franco's regime as an instrument of control and indoctrination. See for example: Manrique, 'La Educación Física femenina'; Teresa González Aja, 'Monje y soldado. La imagen masculina durante el franquismo', RICYDE: Revista Internacional de Ciencias del Deporte (1) (2005): 64-83; Santacana, 'Espejo'.

${ }^{27}$ Juan Carlos Manrique, 'Juventud, deporte y falangismo. El Frente de Juventudes, la Sección Femenina y los deportes del Movimiento', in Atletas y ciudadanos. Historia social del deporte en España (1870-2010), ed. Xavier Pujadas (Madrid: Alianza, 2011), 233-272.

${ }^{28}$ 'Ley de Educación Física de 20 de diciembre de 1961', Boletín Oficial del Estado, 27 Diciembre 1961.
} 
campaign Sports for all, which had the slogan We count on you. This ambitious campaign had a double purpose: firstly, to increase the number of participants in sports and, secondly, to obtain victories in competition at a high level. However, in reality, this campaign was focused on parameters of performance, and therefore it did not contribute to increasing the number of participants (but it helped the middle class man to realise the importance of filling his spare time with sporting activities $)^{29}$. In this scenario, the Physical Education teachers' adherence to the ideology which had been so characteristic of the first years starts declining, and ends up being substituted by a purely professional motivation, which was focused on the technical aspects of the different sports rather than on the communication of a social model ${ }^{30}$.

Finally, it is important to highlight that this change of direction in Physical Education and sports concurred temporarily with the creation of Labour Universities. In fact, most of the changes that took place were mirrored by these education institutions.

\section{Physical Education in Labour Universities.}

At the beginning, Labour Universities suffered the same indoctrinating attempt through Physical Education as the rest of educational institutions did. The teaching in Labour Universities was divided into two main areas: Non-Regulated Vocational Training, aimed towards workers or people outside the education system; and Regulated Vocational Training, which was integrated within the education system and was aimed towards school children or teenagers. Special attention was given to Physical Education in both areas, because physical effort was understood as an essential element to train future 'monk-soldiers', thus strengthening the physical and moral character of the worker and contributing in this way to the consolidation of the Movement.

The obsession of Franco's regime for the improvement of the physical condition of workers and the creation of a 'new man' must be framed within the socio-Darwinian tendencies which became popular in interwar Europe. Physical exercise meant the cornerstone of the regeneration and strengthening of the Spanish race ${ }^{31}$. The education system, and in this case Labour Universities, created the space for the working class to be trained in the arena of physical activity as well as to receive political indoctrination.

In this way, Physical Education helped the youth to move away 'not only from the perils of moral perversion which loom over our young workers, but also from the catastrophic danger of total depersonalization $^{32}$. Therefore physical practice was intended to fill spare time and, overall, to transmit the model of a worker according to the social imagery of the Regime: disciplined, responsible, hard-working and compliant.

The way in which those principles were carried out was through leaving in the hands of the F.J. and the S.F. the vast majority of the responsibilities belonging to Physical Education in these new education institutions. The F.J. and the S.F. determined the objectives and the content, wrote the manuals (which were actual Falangist texts, rather than technical books ${ }^{33}$ ) and chose the teachers (according to their political views rather than to their professional capability).

Therefore this was mostly a political action within Physical Education, which wanted the young

\footnotetext{
${ }^{29}$ González Aja, 'Contamos contigo', 353.

${ }^{30}$ Manrique, 'Juventud, deporte y falangismo', 240.

${ }^{31}$ Although strictly speaking there is not a Spanish 'race', the hierarchs of Franco's dictatorship frenquently used the term, which had clear racist connotations.

${ }^{32}$ Ibíd., 18.

${ }^{33}$ Iván López, 'Manuales escolares de Educación Física en la Segunda Enseñanza (1936-1977)' in Los Manuales de Texto en la Enseñanza Secundaria (1812-1990), ed. María Gómez y Guadalupe Trigueros (Sevilla: Editorial Kronos, 2000), 349-362.
} 
workers to be trained in all the virtues that it was thought that they should have. This fact was essential for the consolidation of the Movement and for the arrival of the aforementioned 'social revolution'. An example of this way of thinking can be found in the magazine La Torre, which was published by the Labour University of Gijón, in the issue 38 of 1961:

'If the young workers do not practice sports, if they go out dancing, looking only for instinctive satisfactions, we are lost. (...) What will happen to our Country if these millions of boys, who are the hope of the future, arrive at the acceptance of their adult responsibilities without preparation, with a lack of human and Christian maturity? ${ }^{34}$.

However, this openly indoctrinating approach only took place during the first years of existence of Labour Universities, as it was one of the last pushes of the Falangist culture. As Payne states ${ }^{35}$, by the end of the Fifties, the base for a more open culture was being established and Falangist ideology had come into its terminal phase. Particularly in the area of Physical Education in Labour Universities, this period saw the change from rigid indoctrinating goals, which belonged to the most fascist period of the Regime, to an idea of Physical Education which even though it did not present an opening character it certainly did present nuances related to sport. However, it is necessary to clarify that these new nuances did not eliminate the level of indoctrination, but instead they made it more subtle, and they contributed especially to the declassing of the young workers.

This new context, which will be described in the next paragraphs, was present at Labour Universities during the majority of their existence and specifically from the beginning of the Sixties until the General Law of Education of 1970 was passed, advocated by the minister Villar Palasí.

\section{The Department of Physical Education and Sport in Labour Universities.}

The Department of Physical Education and Sport was integrated within the Division for Human Training, along with the subdivisions for Religious Training, National Spirit Training, Teaching of Popular Lore and Aesthetic Training. All these disciplines conformed a 'system of teachings and habits aimed towards the spiritual, intellectual, moral and physical development of man. (...) It includes all school students in all grades, and it is developed cyclically and methodically in all grades $^{\prime 36}$. The main task of the Department was to train upright men for the future; men able to fulfill their mission in the technical, social, patriotic, civil and religious areas. In this way, teaching activities had to revolve around Human Training, which had predominance over all subjects, regardless of the vocational or technical calling of the student. From the first hour of the day activities and practical exercises were promoted, with the aim of stimulating the physical and spiritual characters.

The Division for Human Training depended directly on the Principal of the Labour University ${ }^{37}$, which meant an essential change, as Physical Education stopped being controlled solely by the Falange to having the Principal as the main figure who took decisions in this area. However, this did not mean that Physical Education lost its indoctrinating character - according to the documents consulted, Physical Education was used as a tool to impress a strong and unitary nationalistic spirit, in which the idea of serving the Country was reinforced through a ferrous discipline and a group of teachings intrinsic to the subject ${ }^{38}$.

This was a cyclical and methodical teaching system which was aimed towards the creation of the

\footnotetext{
${ }^{34}$ La Torre 38 (1961): 2.

${ }^{35}$ Payne, franquismo. Segunda parte.

${ }^{36}$ 'Orden de 12 de julio de 1956'.

${ }^{37}$ Ibíd., Base 18.

${ }^{38 ،}$ Consideraciones sobre formación humana: plan y realización', in Anales de la Universidad Laboral de Córdoba

Onésimo Redondo (Córdoba: Universidad Laboral de Córdoba, 1961), 12-23.
} 
'new man' in all his physical abilities (or belonging to the body), aesthetic abilities (or belonging to sensitivity), moral abilities (or belonging to the will), and intellectual abilities (or belonging to the intelligence) ${ }^{39}$. Physical Education, just like the rest of the educational subdivisions (religious, cultural and aesthetic training, National Spirit Training, and Teaching of Popular Lore) had the main aim of training upright men for the future, 'men able to fulfill their mission in the technical, social, patriotic, civil and religious areas ${ }^{40}$, stimulating the feeling of service to the Country through physical exercise and discipline.

The teachers at the Department of Physical Education and Sport, just like in the rest of education centers, were under the directions of the Falange. However, unlike other centres, neither the F.J. or the S.F. had complete power in choosing the teachers, but these were appointed after having heard the views of the Principal of the Labour University ${ }^{4}$. This dependency on the highest leader was very important, because in many cases the Principal rooted for excellence in sports as a way of increasing the prestige of the institution, and therefore the teachers, if they wanted to keep their job, had to act accordingly.

It is also important to note that one of the main elements which differentiated Labour Universities and which made them one of the highest exponents of the sports policy which commenced at the end of the Fifties by Elola-Olaso: their sports facilities. Many sports facilities, which are still used today, were built at these macro-institutions. The University Pablo de Olavide in Seville can stand as an example, as it has a track and field space, an indoor pool, sports and fronton courts. All of these facilities were built whilst the University was the Labour University José Antonio Primo de Rivera. The same phenomenon is again demonstrated by the Labour University of Córdoba, established in 1956, which had more than twenty hectares of land and included, among its sports facilities, the first athletics track, an indoors competition pool, and a rugby field ${ }^{42}$. There are numerous other examples of this, as well.

Having outstanding sports facilities which were the envy of other institutions at the time was a very motivating factor to practice sport for the working class youth who studied at these institutions. In fact, in the majority of the cases, this was the only opportunity that the students had to access certain activities, such as swimming, which they could not have practiced otherwise. In addition, other, more popular activities, such as football, also took place in high quality facilities.

An example of the relevance of Labour Universities and their highly developed infrastructures and sports resources is shown in the press of the time. Thus for instance the newspaper ABC highlighted the magnificent sports infrastructures of the new Labour University of Valencia, which had:

'All the sports (...): a three thousand square meters sports gym, an Olympic pool, a large athletics track, fields for basketball, handball, hockey, football, etc. These infrastructures are complemented by a good Department of Physical Education that includes observation rooms, bodybuilding studio, etc. Among them, the following sports are practised: athletics, football, judo, personal defense, hockey, bastketball, handball, fronton... ${ }^{, 43}$.

For the then Secretary of Work, Romeo Gorría, at Labour Universities:

'(...) exceptional circumstances concur, summed up in a triple consideration: Who do they serve? What are they instruments for? And, where are they going? They serve the youth, the spirit of the youth, and on the other hand they are an instrument of the social policy, ${ }^{44}$.

\footnotetext{
${ }^{39}$ Ibíd., 13.

40'Orden de 12 de julio de 1956'.

${ }^{41}$ Delgado-Granados, 'La Universidad de los pobres'.

${ }^{42} A B C$, April 3, 1959.

${ }^{43} A B C$, May 19, 1968

${ }^{44} A B C$, December 18, 1968.
} 


\section{The content of Physical Education.}

The teaching tasks of Physical Education teachers were divided between theory lessons and practice from Monday to Friday, for each of the groups. These lessons were complemented with the competitions that took place on Saturdays and Sundays.

The time spent on sport activities which can be observed in a typical schedule (table 1) gives an idea of how relevant Physical Education was.

Table 1. Typical schedule ${ }^{45}$.

\begin{tabular}{cl}
\hline TIME & \multicolumn{1}{c}{ Activity } \\
\hline 7.00 & Getting up. Grooming and Breakfast \\
8.30 & Gymnastics (daily) \\
9.00 & Theory lessons \\
10.30 & Break \\
11.00 & Practice \\
13.30 & Lunch and break \\
15.00 & Practice \\
16.30 & Sports \\
17.30 & Tea time and break \\
18.00 & Theory lessons \\
19.30 & Practice \\
20.30 & Theory lessons and study \\
21.30 & Dinner and spare time \\
22.30 & Going to bed, praying and silence \\
\hline
\end{tabular}

From the first day of school, teachers introduced their students to a Physical Education which had a clear sports-oriented character, and which was structured with a progression criteria; this is to say, during the first stage the student became familiar with different sports, and lately he specialized in one or more sports ${ }^{46}$. The goal was doublefold: on the one hand, to obtain good results in competitions because this had a positive impact on the prestige of the institution and, by extension, on the prestige of the teacher. On the other hand, to encourage that sport (practiced in fabulous facilities and with the appropriate material) was part of the life of the students, therefore setting them apart from the working class environment from which they came, where the access to certain sports, such as swimming or skiing, was not possible and the practice of more popular sports, such as football, used to take place in deficient facilities.

The contents of Physical Education at Labour Universities, which are shown at table 2, were divided according to the age of the students.

Table 2. Physical Education Plan ${ }^{47}$

\begin{tabular}{|l|l|l|}
\hline Stages of the Plan & \multicolumn{1}{|c|}{ Goal } & \multicolumn{1}{c|}{ Development } \\
\hline & & Educational Gymnastics \\
$10-12$ year-olds & $\begin{array}{l}\text { Physical and physiological } \\
\text { improvement }\end{array}$ & $\begin{array}{l}\text { Utilitarian and rhythmical exercises } \\
\text { Marching and Walks } \\
\end{array}$ \\
& Swimming \\
\hline
\end{tabular}

\footnotetext{
${ }^{45}$ Ministerio de Trabajo, Universidades Laborales (Madrid: Servicio de Publicaciones del Ministerio de Trabajo, 1967). ${ }^{46}$ Ibíd.

${ }^{47}$ Delegación Nacional de Educación Física y Deporte, Boletín de la Delegación Nacional de Educación Física y Deporte (Madrid: Delegación Nacional de Educación Física y Deporte, 1962).
} 


\begin{tabular}{|l|l|l|}
\hline 13-14 year-olds & $\begin{array}{l}\text { Psycho-physiological } \\
\text { improvement }\end{array}$ & $\begin{array}{l}\text { Educational Gymnastics } \\
\text { Pre-sports and sports games and competitions } \\
\text { Utilitarian and rhythmical exercises } \\
\text { Marching and Walks }\end{array}$ \\
\hline 15-17 year-olds & Technical and Sports Training & $\begin{array}{l}\text { Educational Gymnastics } \\
\text { Pre-sports and sports } \\
\text { Sports application exercises } \\
\text { Marching and Precision cross } \\
\text { Swimming } \\
\text { Sporting competitions }\end{array}$ \\
\hline $18-21$ year-olds & Sports Technical Entertainment & $\begin{array}{l}\text { Educational Gymnastics } \\
\text { Specific sports } \\
\text { Sports application exercises } \\
\text { Marching and Precision cross } \\
\text { and Confirmation of the }\end{array}$ \\
& personality & $\begin{array}{l}\text { Swiming } \\
\text { Sporting competitions }\end{array}$ \\
\hline
\end{tabular}

In regards to Table 2, it is important to highlight that initially Physical Education was focused on what was called Educational Gymnastics, which had a corrective and specific character. However, as the students grew older this type of gymnastics lost preponderance and became focused on muscular strengthening (which was necessary for many of the occupations for which the students were being trained). The place of Educational Gymnastics was gradually replaced by sports, and in the last phase there were even sports related to the specific work specialties. Horse riding, for example, was compulsory for students of the agricultural specialty ${ }^{48}$.

The array of sports was characterised by its ample variety, which allowed the student to choose at least one of the sports which were offered at the institution: basketball, handball, football, competitive swimming, water polo, tennis, rugby, skiing, rowing and mountaineering. There were, additionally, frequent extracurricular activities of a sports character, as well as sporting competitions. There were two types of sporting competitions ${ }^{49}$ :

-Internal competitions: collegiate and intercollegiate. All the students within the clubs of the Labour University participated in these competitions, according to the different categories (children, youth, and amateur).

-External competitions, which were divided into collegiate and federate. Within the collegiate rank, the students competed in the National School Games in the junior and youth categories, and at the University Games in the senior category. Within the federate rank, the students participated in the provincial competitions organised by various sports federations, in the specialties of athletics, rugby, volleyball, football, etc.

Picture 2. Students who participated in national sporting competitions ${ }^{50}$.

The desire to equate Spain with the rest of the European countries, which were ahead in terms of physical training and sporting competitions, led to the creation of the Sports for all campaign, which, as noted before, had a larger impact on sporting competitions than on the increase of participants. In this context the various Labour Universities developed campaigns which encouraged the participation and competition among the young students. The practice of sports and the participation in competitions, both as amateurs and as professionals, were encouraged through the games, whether collegiate, university or syndicate games. Sports became a very important part of the students' life, who were either participants or followers of the different university teams, and who in this way became involved with all that was related to sports whilst they were distracted from

\footnotetext{
${ }^{48}$ Ibíd.

${ }^{49}$ Ministerio de Trabajo, Universidades Laborales. Reunión de su Consejo Técnico, 3 de marzo de 1958 (Madrid: Servicio de Mutualidades Laborales, 1958).

${ }^{50}$ Sección de Educación. Universidades Laborales, 'Universidad Laboral de Gijón, 1960', Legajo 19170, Archivo General de la Administración.
} 
issues that bothered the Regime, such as strikes and workers' demands, which at that time had started to flourish in several areas of Spain.

The magazine 'Horizontes', from the Labour University of Seville José Antonio Primo de Rivera, published this news, which also highlighted that the virtues of the Spanish youth in sports were a result of the virtues at work:

\begin{abstract}
'Do not doubt that the Spanish people, with their high volume of radical virtues, with their intuition, imagination and decision, will in a short time be able to achieve the quantity and quality of young athletes who, with an Olympic spirit, will manage to improve and excel while achieving glory and prestige for Spain within the context of international competitions, ${ }^{51}$.
\end{abstract}

It was also common for Labour Universities to publicise the activities which took place in their centres, including the names of the participants. Thus, for example, the magazines of the various institutions published monthly the sporting events at their centres, stating the efforts of their students and noting their splendid sporting facilities, which, as previously stated, were unthinkable at the time (in Seville, for instance, the Olympic swimming pool was the only one in the city; in Gijón, the fronton tracks stood out).

In short, it was a matter of promoting a sports awareness within the students of the working class through regular activities and sports facilities, such as football fields, athletics, gymnastics, swimming pools, etc., which transformed the hobbies and sports practices into an everyday activity for young students. In this way, these activities took the students away from their original environments, and of course, they were also a very effective tool to prevent the existence of a fighting spirit for the rights of the agricultural and industrial worker. Over the years, Labour Universities became real quarries for the promotion of the young workers - athletes and classless.

\title{
Villar Palasí's General Law of Education (1970): new educational approaches.
}

The economic and social development which took place in Spain from the beginning of the 1960s demanded a reform of the educational system. On a productive level, it was necessary to have an educational system which eliminated the ideological aspects and increased notably the technical and scientific content of the syllabus, since the industrialisation of the country required qualified labour. On a social level, a change was demanded to include the principle of equal educational opportunities, to overcome the traditional double system of primary education (a system for children who could further their studies due to their financial position, and a system without access to further education for those who could not), in order to promote the access to further education depending on aptitude, rather than wealth.

The adoption of the Law on Education and Financing from the Educational Reform ${ }^{52}$, which was promoted by the then Minister of Education Villar Palasí, addressed these demands, standing as a turning point between the dictatorship and the transition to democracy.

The Law meant a noticeable progression in the social and educational consideration of Physical Education. Thereafter, there was an emphasis on aspects related to the aesthetical, physiological, and physical development, amongst other aspects, with the intention of reaching a more educational interest in physical activities which would promote the evolution of the student's personality in a holistic way, and which would really promote the sports practice among all students, and not only among the better equipped physically. Therefore it started a period in which Physical Education was freed from the indoctrinating character which it had previously had.

\footnotetext{
${ }^{51}$ Revista Horizontes 25 (1962): 29.

${ }^{52}$ 'Ley 14/1070 General de Educación y Financiamiento de la Reforma Educativa de 4 de Agosto de 1970'.
} 
Consequently, since 1970, and relying on the ideas of the educational reform, the activities plan of Physical Education at Labour Universities was expanded and bolstered through a series of initiatives translated as artistic and sporting activities of various kinds, according to the student's preferences and interests ${ }^{53}$. Thus, for instance, the Labour University of Gijón, in relation to sporting activities, built the Summer University which was aimed towards outdoor sports activities, promoting new proposals such as introduction to mountaineering, high mountain camping, skiing, or shooting sports.

Each school belonging to their respective Labour University created a training plan which included all kinds of extracurricular and residential activities, among which the sport activities had a very relevant role. These activities acquired greater importance on Friday afternoons, Saturdays, and Sundays. During those days, a special emphasis was placed on human values, coexistence, outdoor leisure sports and so forth. As an illustrative example, it is useful to highlight the variety of subjects that were included in the Plan for Human Training of the academic year 1976-1977, which involved 20 educators, 6 teachers, and all the school delegates ${ }^{54}$ :

Table 3. Plan for Human Training (1976-1977).

\begin{tabular}{|c|c|}
\hline Outdoor activities & Outdoor sports \\
\hline Artistic and recreational activities & Cinema and theatre \\
\hline Cultural activities & Outings, workshops, conferences, etc. \\
\hline
\end{tabular}

In relation to the activities related to Physical Education which are proposed in this Plan for Human Training, it is important to highlight their diametric difference with the activities proposed in the period prior tothe General Law of Education, where traditional sports ruled and competition was their common denominator. In regards to these changes, it is important to highlight not only the fact that the students, through their delegates, had a say in the choice of sports activities, but also that the activities had a notable integrative and recreational character. In fact, there was a special interest in the educational, social and physical benefits that the practices could confer, while the sole goal of winning that had predominance during the previous period, now took second place.

It became a matter of showing the benefits and virtues of Physical Education through the practice of a set of activities scheduled at the Labour Universities, which, in many cases, were accompanied by songs and dances that were practiced by the Choir and Dances groups all over Spain.

From the early 1970s until the closure of Labour Universities in 1978, an increasing interest towards pedagogical aspects and the use of leisure time through sport can be observed. Physical Education released the imposed moral values, as well as of the requirement for sporting performance which was characteristic of the 1960s.

\section{Conclusions.}

This research examines the role of Physical Education in Franco's Labour Universities (1955-1978) as an instrument of indoctrination of the working class. The key finding in this regard is that, at the beginning, Physical Education at the Labour Universities, as in the rest of the Spanish educational institutions, followed the clear and manifest indoctrinating precepts imposed by the Regime, but a few years after the creation of these institutions, consistent with the political changes in regards to sports, the pursuit of sports performance jumped to the foreground. In this second phase, which covers much of the existence of these universities, the indoctrinating aspect had a more subtle

\footnotetext{
${ }^{53}$ Ministerio de Trabajo, Universidades Laborales (Madrid: Ministerio de Trabajo. Dirección General de Promoción Social, 1975).

${ }^{54}$ Carlos Labrador, El sistema educativo de la Compañía de Jesús (Madrid: UPCM, 1987).
} 
character, which contributed to the declassing of the young workers.

There were two basic tools for this declassing task. On the one hand, there were splendid sports facilities (indoor pools, football fields, volleyball fields, track and field spaces and so forth), which contributed to the motivation towards the practice of sport. On the other hand, there was the continuous proposal of sport activities, not only through Physical Education lessons, but also through competitions and trainings associated with the lessons. Moreover, these activities were not restricted to the typical sports of the working class, such as football, but they included other sports, such as swimming, skiing, or tennis, which otherwise would have been virtually inaccessible to the young workers.

The purpose of both tools was to create a habit of participating in sports, which together with teachings of morality and the vocational training that these young workers received (as opposed to different training given to other workers) separated the young workers from their origins, thus creating a new type of worker: well trained, non-protesting, and allied with the Regime.

The third and last phase of Physical Education in Labour Universities commenced with the General Law of Education of 1970. From then and until the closure of these institutions in 1978, the participating, pedagogical and holistic training aspects of Physical Education reached an important level, portraying Physical Education as a healthy, aesthetic and entertaining activity, thus showing that its competitive aspect was not the only possible one and letting go of the indoctrinating character that had been blatant until the end of the 1950s and more subtle during the 1960s.

Finally, it is important to highlight that the current configuration of Physical Education and sport in Spain is closely related to the development period of Franco's Regime. It is evident the momentum provided by Labour Universities during that time because, for more than twenty years (1955-1978), they were the largest education centres in Spain, standing out due to their role in sports and their architecture (they have left superb infrastructures, which after remaining in total abandonment, are now being exploited and reused for educational and sporting purposes). 